\title{
EFFECT OF MICROALGAE ON GROWTH AND FATTY ACID PROFILES OF HARPACTICOID COPEPOD, Tisbe holothuriae
}

\author{
Gede Suwarthama Sumiarsa \# and Philip Teguh Imanto \\ Research Institute for Mariculture
}

\begin{abstract}
Growth of marine copepods is influenced by feed. The purposes of this trial were to observe both growth and fatty acid compositions of harpacticoid copepod nauplii, Tisbe holothuriae by feeding with several microalgal species in laboratory: (A) Isochrysis tahiti; (B) Nannochloropsis oculata; (C) Rhodomonas sp., and (D) Tetraselmis chuii. The trial was carried out for 35 days with randomized complete design and triplicates in each treatment. The results showed that final copepod nauplii densities were not significantly different $(P>0.05)$ in all treatments. However, lipid content of copepod nauplii fed with $T$. chuii was significantly higher $(P<0.05)$ compared to that of other treatments while fatty acid profiles of EPA, DHA and DHA/EPA ratios showed both insignificant and significant differences among treatments.
\end{abstract}

\section{KEYWORDS: fatty acids, harpacticoid copepods, microalgae, Tisbe holothuriae}

\section{INTRODUCTION}

Copepods are one of the most abundant organisms and its biomass makes up the greatest portion of marine zooplankton population (Hickman, 1993). With over 11,500 species, they are more numerous than insects on land, even though insects are far more diverse (Humes, 1994). From a nutritional standpoint, copepod nauplii are often considered nutritionally better than rotifers (Brachionus sp.), brine shrimp (Artemia sp.) (Stottrup et al., 1998), and oyster trochophores (Lim, 1991; Doi \& Singhagraiwan, 1993). One reason why copepod nauplii might be nutritionally better than other live food sources is that they have high content of HUFA (highly unsaturated fatty acids), PUFA (poly unsaturated fatty acids), and other fatty acids needed to meet the nutritional requirements of a fish's early ontogeny (Witt et al., 1984). In fish hatcheries, copepod nauplii are preferred as the first live food for many fish species larvae such as gadoid larvae (Last,
1978), red snapper, Lutjanus campechanus (Rabalais et al., 1980), walleye Pollock, Theragra chalcogramma (Dagg et al., 1984), turbot (Witt et al., 1984), mahimahi, Coryphaena hippurus (Kraul, 1991), the cod, Gadus morhua (van der Meeren \& Naess, 1993), gilthead seabream, Sparus aurata (Fernandez et al., 1994), halibut, Hippoglossus hippoglossus (Harboe et al., 1994), mangrove snapper, Lutjanus argentimaculatus (Doi et al., 1994), grouper, Epinephelus coioides (Kohno et al., 1997; Su et al., 1997), dhufish, Glaucosoma hebraicum and pink snapper, Pagrus auratus (Payne et al., 2001). Due to both high nutritional value and high abundance in natural waters, the use of copepods as live feed for larval fish in hatcheries should be encouraged and developed.

It has been reported that generally, copepods feed on microalgal diets and bacteria (Treece, 2000). Copepods will response differently to microalgal diets which particularly

\# Corresponding author. Research Institute for Mariculture, Jl. Br. Gondol, Kec. Gerokgak, Kab. Buleleng, Kotak Pos 140, Singaraja, Bali 81101 , Indonesia. Tel.: + (0362) 92278; Fax. (0362) 92272 E-mail address: gedess@hotmail.com 
influence copepods ability to produce eggs and viability of copepod's egg hatching rate (lanora, 2005). In addition, there are numerous reports regarding the advantages and disadvantages of feeding copepods with particular microalgal species.

To increase fish seed production to support aquaculture in Indonesia, breakthroughs are required in the field and one of them is by introducing an intensive finfish hatchery program at the Research Institute for Mariculture Gondol, Bali by Danish Institute for Fisheries Research (DIFRES). The intensive hatchery has been equipped with seawater recycling system to meet with environmental safety and friendly standards. One of the introduced components was a harpacticoid copepod species, Tisbe holothuriae to produce nauplii for early feeding of produced finfish larvae (Steenfeldt et al., 2002).

The purpose of this experiment was to observe daily densities of harpacticoid copepod nauplii, Tisbe holothuriae and to find out their fatty acid compositions after fed with four different microalgal species i.e.: Isochrysis tahiti Nannochloropsis oculata, Rhodomonas sp., dan Tetraselmis chuii in laboratorial scale.

\section{MATERIALS AND METHODS}

\section{Production of Microalgae}

All four microalgal species of I. tahiti; $N$. oculata, Rhodomonas sp., dan T. chuii were produced in 80-L hanging carbuoys exposed to 40-W fluorescent lamps with average air tempaerature of about $24^{\circ} \mathrm{C}$ in an air conditioned controlled room. Medium used and operational culture procedure followed Steenfeldt et al. (2002).

\section{Production of Copepod Nauplii}

The experimental unit was a round conical bottom of $0.5 \mathrm{~m}^{3}$ black fiberglass tank provided with arranged $60 \mathrm{~m}^{2}$ polycarbonate substrate for adult harpacticoid copepod $T$. holothuriae to attach. Production method for copepod nauplii in the laboratory was carried out according to Steenfeldt et al. (2002).

\section{Trials}

Copepod nauplii were harvested from the original culture tanks through stratified filtration, pooled and counted according to volu- metric sampling method. A number of adult copepods were stocked into prepared tanks together with the nauplii. The remaining adults were stocked back into their original culture tanks. The pooled nauplii and adult copepods were then fed with four microalgal diets at a density range of $1.0-12.0 \times 10^{5}$ cells $/ \mathrm{mL}$ in one tank for $24 \mathrm{~h}$ before starting the trial to minimize bias due to their preference to a particular microalgal diet. Before stocking into twelve experimental units, those nauplii and adult copepods were counted and divided evenly.

The microalgal treatment diets were:
(A) I. tahiti;
(B) N. oculata;
(C) Rhodomonas sp., and
(D) T. chuii

Each treatment was in triplicates. Copepod nauplii were counted every morning during the trial while microalgae were added into each experimental unit in interval of 2-4 days. Water volume in each experimental tank was lowered through filtration before adding the microalgae. All nauplii and adult copepods retained in the filter were stocked back into their represented experimental tanks. Microalgae and copepod nauplii enumeration were conducted according to Boyd \& Tucker (1992). Water quality observation was conducted twice a week i.e. dissolved oxygen and total ammonium, while water temperature and salinity were checked daily. The trial was carried out for 35 days.

All twelve experimental tanks were rinsed and dried well at the end of the trial. Copepod nauplii were separated with the adults by stratified filtration. The latter were cultured back for future use while the harvested nauplii samples were prepared according to modified procedures of Kates (1986) and Christie (1987) for further lipid and fatty acid analyses. Lipid extraction and fatty acid analysis were carried out at the Center for Food and Nutrition Laboratory of Gajah Mada University, Yogyakarta. Lipid extraction was conducted according to Soxhlet method while fatty acid analysis was carried out using a GC 14 B Shimadzu with 50-m capillary column CBP- 10. Column temperature was set at $180^{\circ} \mathrm{C}-240^{\circ} \mathrm{C}$ with heating rate of $2.5^{\circ} \mathrm{C} /$ minute. Both injector and detector temperatures were $250^{\circ} \mathrm{C}$ with Helium gas as carrier at pressure of $180 \mathrm{kPa}$. 
Detector used was FID (Flame Ionization Detector) integrated with Shimadzu C-RGA. Standard solutions used were Supelco ${ }^{\circledR}$ (U.S.A) Cat. \# 47801 and Cat. \# 178241A (for EPA: eicosapetaenoic acid and DHA: docosahexaenoic acid).

Observed values in this trial were expressed in average \pm standard error. Data were analyzed in $t$-test of ANOVA with $\mathrm{SAS}^{\circledR}$ Version 6.12 for Windows ${ }^{\circledR}$ (SAS Institute, Inc., Cary, North Carolina, 1996). Least significant difference (LSD) was applied if significant differences among treatments were found (Sokal \& Rohlf, 1981). Differences were assumed significant at a probability level, $\mathrm{P}=0.05$. Computer softwares used in data analysis and reporting were Microsoft ${ }^{\circledR}$ Excel XP and Microsoft Word $X P$.

\section{RESULTS AND DISCUSSION}

Average daily densities of harpacticoid copepod nauplii, T. holothuriae and microalgal in all treatments were depicted in Figure 1 and 2 while lipid and fatty acid compositions of copepod nauplii were shown in Table 1. Initial densities of stocked microalgae of I. tahiti (3.0$10.0 \times 105$ cells $/ \mathrm{mL})$ and $N$. oculata $(10.0-40.0$ $x 105$ cells $/ \mathrm{mL}$ ) were higher than that of the
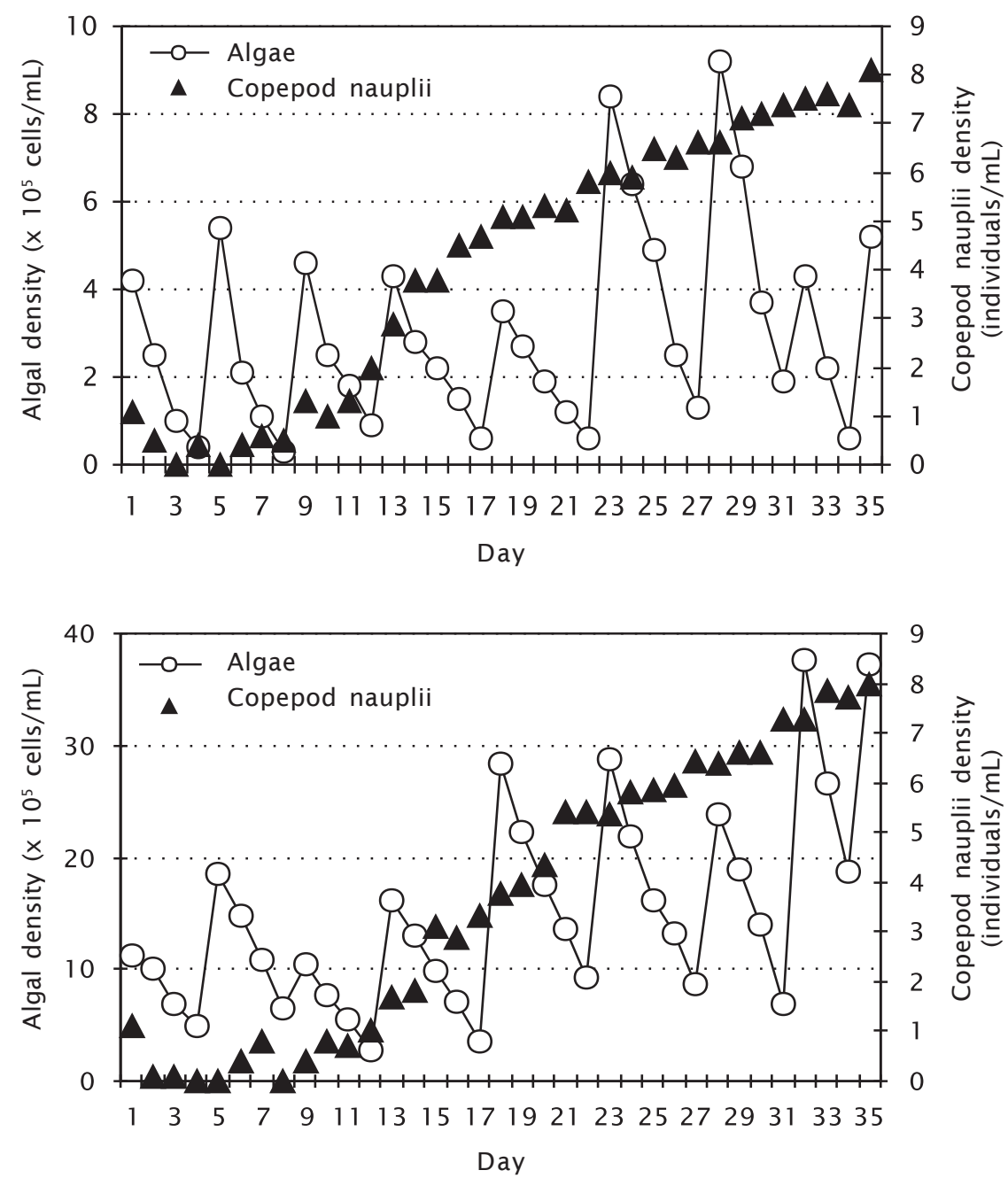

Figure 1. Daily average densities of harpacticoid copepod nauplii T. holothuriae fed with I. tahiti (top) and N. oculata (bottom) 
other stocked microalgae species (1.0-3.0 x 105 cells $/ \mathrm{mL}$ ). Initial nauplii and adult copepod densities in each experimental unit were estimated at $1.1 \pm 0.1$ and $0.6 \pm 0.0$ individuals $/ \mathrm{mL}$, respectively while at the end of the trial, copepod nauplii densities were between 8 and 11 ind./mL. Copepod nauplii density elevated after 8-13 days of the trial. There were no significant differences of copepod nauplii densities among treatments at the end of the trial. However, there was significant differences in term of lipid content in copepod nauplii in this trial $(P=0.04)$. Lipid content of copepod nauplii fed with $T$. chuii (6.7\%) was signifi- cantly higher $(P=0.03)$ compared to that of fed with N. oculata. Eicosapentaenoic acid (EPA) content was significantly higher $(P=0.02)$ in copepod nauplii fed with $N$. oculata $(60.5 \mathrm{mg} /$ $100 \mathrm{~g})$ but contained the lowest docosahexaenoic acid (DHA, $5.7 \mathrm{mg} / 100 \mathrm{~g}$ ) resulted in the lowest DHA/EPA ratio of $0.1(\mathrm{P}=$ $0.02)$. DHA/EPA ratio is considered important because both fatty acids are essential fatty acids for marine finfish larvae (Sargent et al., 1997). As reported by Kanazawa (1990) in Waspada et al. (1991) that DHA/EPA ratio in tiger grouper larvae (Epinephelus fuscoguttatus) was 5.8. In addition, requirement of essential
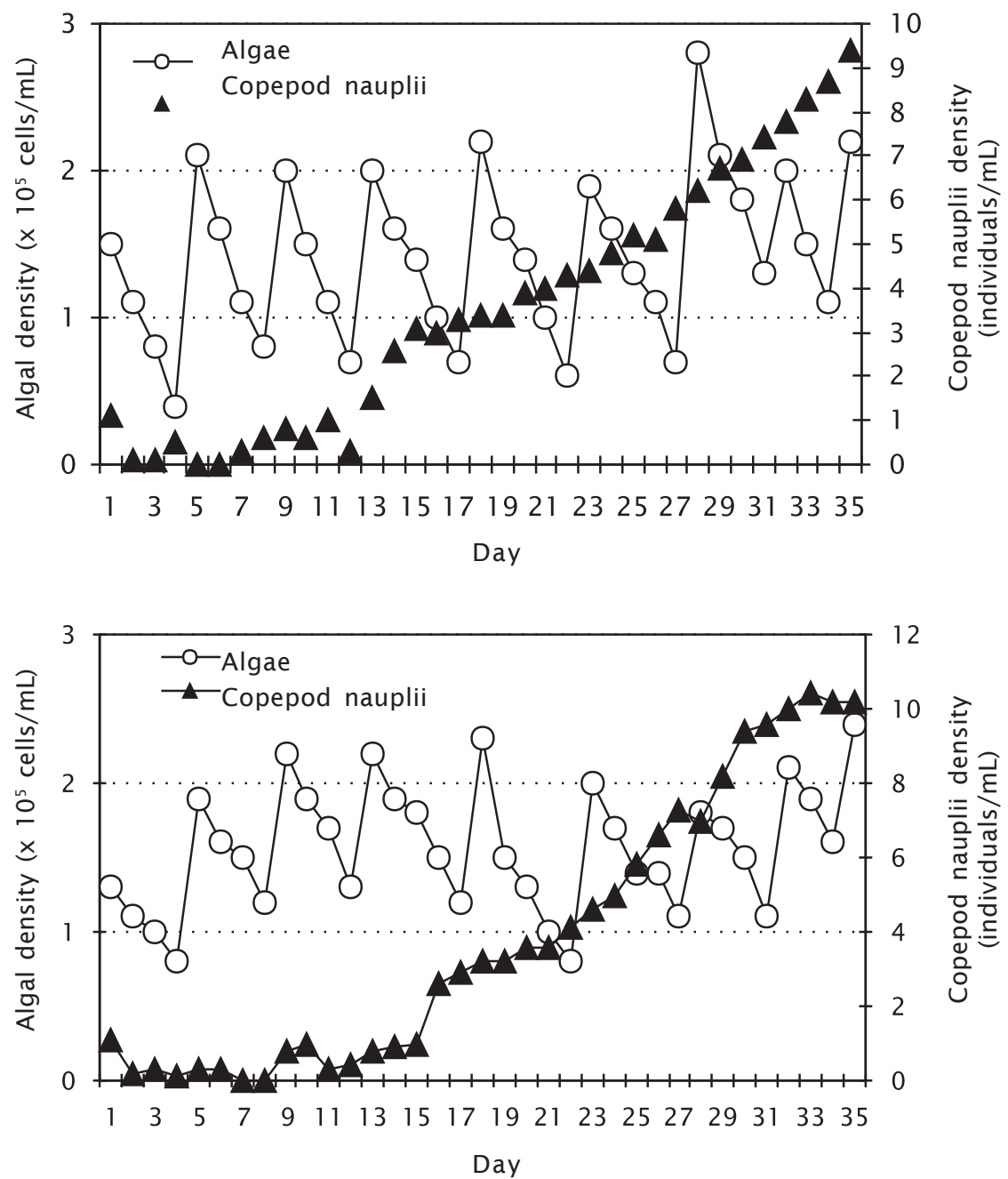

Figure 2. Daily average densities of harpacticoid copepod nauplii T. holothuriae fed with Rhodomonas sp. (top) and T. chuii (bottom) 
Table 1. Fatty acid (mg/100 g dry weight) and lipid contents (\% dry weight) of harpacticoid copepod nauplii $T$. holothuriae fed with four microalgal species

\begin{tabular}{lcccc}
\hline \multirow{2}{*}{ Fat y acids s } & \multicolumn{4}{c}{ Copepod nauplii fed with- } \\
\cline { 2 - 5 } & I. tahiti & N. oculata & Rhodomonas $\mathbf{s p .}$ & T. chuii \\
\hline $8: 00$ & 7.3 & 6.1 & & \\
$12: 00$ & 12.2 & 18 & 23 & 9.2 \\
$14: 00$ & 7.2 & 7.7 & 14.6 & 10.7 \\
$14: 1 \mathrm{n}-9 \mathrm{c}$ & 177.2 & 285.9 & 142.7 & 338.5 \\
$16: 00$ & 94 & 143.5 & 107.4 & 143 \\
$16: 1 \mathrm{n}-9 \mathrm{c}$ & 33.5 & 50.2 & 90.2 & 28.2 \\
$17: 00$ & 41.8 & 22 & 24.6 & 39.4 \\
$18: 00$ & 281.7 & 239.3 & 325 & 706.3 \\
$18: 01$ & 231.7 & 459.5 & 367.5 & 439.9 \\
$18: 2 \mathrm{n}-6 \mathrm{c}$ & 44.7 & 17.2 & 60.6 & 321.7 \\
$18: 3 \mathrm{n}-3$ & 12.6 & 6.9 & & 51 \\
$20: 00$ & 21.3 & 36.4 & 28.1 & 57.5 \\
$20: 01$ & $18.9^{\mathrm{a}}$ & $60.5^{\mathrm{b}}$ & $47.0^{\mathrm{b}}$ & $42.5^{\mathrm{b}}$ \\
$20: 5 \mathrm{n}-3$ (EPA) & $33.3^{\mathrm{a}}$ & $5.7^{\mathrm{b}}$ & $65.8^{\mathrm{c}}$ & $55.6^{\mathrm{ac}}$ \\
$22: 6 \mathrm{n}-3$ (DHA) & $1.8^{\mathrm{a}}$ & $0.1^{\mathrm{b}}$ & $1.4^{\mathrm{a}}$ & $1.3^{\mathrm{a}}$ \\
DHA/EPA & $4.6^{\mathrm{ab}}$ & $3.7^{\mathrm{a}}$ & $4.8^{\mathrm{ab}}$ & $6.7^{\mathrm{b}}$ \\
Lipid (\%) & &
\end{tabular}

1. Standard errors of average are not given for clarity of values

2. Values followed by the same superscript are not significantly different $(\mathrm{P}>0.05)$

fatty acids corresponds to fatty acid contents in fish body. From the results, it can be seen that DHA/EPA ratios of copepod nauplii in all treatments were below the DHA/EPA ratio of tiger grouper larvae. The highest ration was found in copepod nauplii fed with I. tahiti (1.8).

Copepod nauplii fed with microalgae $I$. tahiti showed significantly lower lipid content $(4.6 \%, \mathrm{P}=0.04)$ compared to the nauplii fed with microalgae $T$. chuii (6.7\%). It has been widely known that microalgae $I$. tahiti contains essential fatty acids with high DHA/EPA ratio. Gimin (2004) reported lipid content of microalgae I. tahiti 23.7\% and Anonimous (2006) reported $17 \%$ with DHA/EPA ratio of 4.1 . However, this trial showed that high lipid content of microalgae did not affect lipid content of the copepod nauplii. As reported by Rhodes \& Boyd (2005) that quality of copepod would not be affected by good microalgae as food. Fleeger (2005) reported that some harpacticoid copepods were able to synthesize longerchained HUFA which will eventually increase the levels of n-3 fatty acids that are essential to fishes. It is also suggested that harpactioid copepods have enzymes (i.e. $\Delta-5, \Delta-6$ desaturase and elongase) that are necessary for the conversion of shorter chain n-3 polyunsaturated fatty acids to the longer-chained essential fatty acids of DHA and EPA. On the other hand, Okauchi et al. (1990) reported that $N$. oculata had no DHA resulted in zero DHA/ EPA ratio. This trial showed low content of DHA in copepod nauplii fed with $N$. oculata. Lipid content of copepod nauplii fed with microalgae I. tahiti was lower than that of fed with T. chuii but it had the highest DHA/EPA ratio compared to that of the other three treatments though did not differ significantly $(P=0.07)$ to that of fed with microalgae Rhodomonas sp. and $T$. chuii.

Reports on proximate analysis of copepod nauplii are scarcely available other than the general reports on proximate analysis of adult copepod from natural waters. Sumiarsa (2003) reported that lipid contents of cyclopoid copepod nauplii Apocyclops panamensis cultured in fertilized earthen ponds were between $5.7 \%$ - 
$7.8 \%$ with DHA/EPA ratios of 1.6-2.4 while the lipid contents of nauplii enriched with several commercial enriching agents were between 5.7-10.8 with DHA/EPA ratios of 1.0-3.3.

In natural temperate and tropical salt water systems, copepod abundance is generally low. Densities of 0.6 to 100 of calanoid, harpacticoid and cyclopoid copepod nauplii/ $\mathrm{L}$ are commonly found in natural waters (Fukusho, 1991; Mishra \& Panigrahy, 1996; Shansudin et al., 1997; Watanabe et al., 1998). In the present trial, final copepod nauplii densities were in between of that in natural waters between 8 and 10 ind./mL.

The feasibility of culturing copepods in laboratory environments has been investigated including intensive indoor systems (Stottrup et al., 1986; Vilela, 1992; Sun \& Fleeger, 1995; Turk et al., 1998; Schipp et al., 1999). In laboratory trials where copepods have been produced in smaller volume systems, average densities of 185 calanoid copepod nauplii Acartia sp./L (Schipp et al., 1999) to 5,150 harpacticoid copepod nauplii Tisbe holothuriae/L (Stottrup et al., 1986) have been produced. Maximum density of 26,000 harpacticoid copepod nauplii Tigriopus brevicornis/L (Vilela, 1992) and 33,000 cyclopoid copepod nauplii $A$. royi/L (Cheng et al., 2001) have been reported in laboratory systems. However, intensive laboratory copepod production systems have been difficult to maintain over extended periods of time (Stottrup \& Norsker, 1997).

Water quality parameters were in the ambient ranges for copepod culture i.e. temperatures were $22^{\circ} \mathrm{C}-24^{\circ} \mathrm{C}$, dissolved oxygen were $3.5-4.1 \mathrm{mg} / \mathrm{L}$, salinity was $34 \mathrm{ppt}$ and total ammonia were $0.27-0.44 \mathrm{mg} / \mathrm{L}$.

In general, all four microalgal species did not give any significant difference in final copepod nauplii density. However, lipid and fatty acid profiles of copepod nauplii fed with $N$. oculata showed inferior values compared to the other treatments.

\section{CONCLUSION}

With regard to the final quantity after seven weeks of trial, harpacticoid copepod $T$. holothuriae responded similarly to the four microalgal species, and there was no significant differences in the final nauplii density. Microalgal species could be fed based on their economical and conditional considerations. However, in term of lipid quality, harpacticoid copepod nauplii fed with $T$. chuii gave the highest lipid content although with inferior DHA/ EPA ratio compared to the nauplii fed with $I$. tahiti. Feeding of high-lipid content microalgal species did not produce similar microalgal lipid levels in harpactiocid copepod nauplii in this trial. It is then suggested that further studies on microalgal species that can boost the lipid content in copepod nauplii have to be conducted.

\section{ACKNOWLEDGEMENT}

The authors whish to thanks staffs of both MSP and Chemistry Laboratories of GRIM: Dadang Rusmana, Siyam Sujarwani, Desi N., Ketut Arya Sudewa, Ayu Kenak, Ari Arsini, and Kadek Ani, whithout them this trial would be impossible. This trial was funded by APBN DIPA 2008 No. 001/XXXII/022/-/2008.

\section{REFERENCES}

Boyd, C.E. \& Tucker, C.S. 1992. Water quality and pond soil analyses for aquaculture. Alabama Agricultural Experiment Station. Auburn University, Alabama, USA. 183 pp.

Cheng, S.-H., Chen, H.-C., Chang, S.-L., Chen, T.-I., \& Liao, I-C. 2001 . Study on the optimal density of mass culture in copepod Apocyclops royi. Sixth Asian Fisheries Forum Book of Abstracts. $58 \mathrm{pp}$.

Christie, W.W. 1987. Lipid analysis: isolation, separation, identification and structural analysis of lipids. Pergamon Press. OxfordNew York-Toronto-Sydney-Braunschweig.

Dagg, M. J., Clarke, M.E., Nishiyama, T., \& Smith, S.L. 1984. Production and standing stock of copepod nauplii, food items for larvae of the walleye pollock Theragra chalcogramma in the southeastern Bering Sea. Marine Ecology Progress Series, 19: 716.

Doi, M. \& Singhagraiwan, T. 1993. Biology and culture of the red snapper, Lutjanus argentimaculatus. The Eastern Marine Fisheries Development Center (EMDEC). Department of Fisheries, Ministry of Agriculture and Cooperatives, Kingdom of Thailand 51: $1-51$.

Doi, M., Singhagraiwan, T., Singhagraiwan, S., \& Ohno, A. 1994a. An investigation of copepods being applied as initial food organisms for red snapper. Thai Marine Fisheries 
Research Bulletin, 5: 21-26.

Fernandez, D., Pascal, C.E., \& Yufera, M. 1994. Feeding behaviour and prey size selection of gilthead seabream, Sparus aurata larvae fed on inert and live food. Marine Biology, $118(2)$ : 323-328.

Fleeger, J.W. 2005. The potential to mass-culture harpacticoid copepods for use as food for larval fish. In Lee, C.S., O'Bryen, P.J., \& Marcus, N.H. (Eds.). Copepods in Aquaculture. Blackwell Publishing, lowa. U.S.A. p. $11-24$

Fukusho, K. 1991. Review of the research status of zooplankton production in Japan. Rotifer and Microalgae culture systems. Proceedings of a U.S-Asia Workshop, Honolulu, Hawaii. U.S.A.

Gimin, R. 2004. The use of recently tropical marine microalgae for reproductive conditioning of the mangrove clam, Polymesoda erosa (Solander, 1786). Makalah Penunjang Simposium Nasional Perikanan Budidaya Berkelanjutan, Denpasar 4-5 Oktober 2004. Pusat Riset Perikanan Budidaya dan Masyarakat Akuakultur Indonesia (in press).

Harboe, T., Huse, I., \& Oie, G. 1994. Effects of egg disinfection on yolk sac and first feeding stages of halibut (Hippoglossus hippoglossus L.) larvae. Aquaculture, 119: 157-165.

Hickman, C.P. 1993. Integrated principles of zoology. In L. Robert Jr., L., \& Larson, A. (eds.). Ninth Edition. Mosby-Year Book, Inc., St. Louis, Missouri, USA. 489: 503-504.

http://www.aquatext.com/tables/isochry.htm

Humes, A.G. 1994. How many copepods? Hydrobiologia 292/293:1-7

lanora, A. 2005. Birth control effects of diatoms on copepod reproduction: Implications for aquaculture studies. In Lee, C.S., O'Bryen, P.J., \& Marcus, N.H. (Eds.). Copepods in Aquaculture. Blackwell Publishing, lowa. U.S.A. p. 31-48

Kates, M. 1986. Techniques of lipidology: isolation, analysis and identification of lipids. $2^{\text {nd }}$ Revised Edition. Elsevier. Amsterdam New York - Oxford.

Kohno, H., Ordonio-Aguilar, R.S., Ohno, A., \& Taki, Y. 1997. Why is grouper larval rearing difficult? An approach from the development of the feeding apparatus in early stage larvae of the grouper, Epinephelus coioides. The Ichthyological Society of Japan, 44: 267-274.
Kraul, S. 1991. Hatchery methods for the mahimahi, Coryphaena hippurus, at Waikiki Aquarium. In McVey, J.P. (eds.). CRC Handbook of Mariculture, Volume II, Finfish Aquaculture. CRC Press, Inc., Boca Raton, Florida, USA. p. 241-250.

Last, J.M. 1978. The food of three species of Gadoid larvae in the eastern English Channel and southern North Sea. Marine Biology, 48: 377-386.

Lim, L.C. 1991. Larviculture of the greasy grouper (Epinephelus tauvina F.) and brownmarbled grouper ( $E$. fuscoguttatus F.) in Singapore. In Lavens, P., Sorgeloos, P., Jasper, E., \& Ollevier, F. (eds.). Larvi '91 - Fish and crustacean larviculture symposium. Special Publication No. 15, European Aquaculture Society, Ghent, Belgium. p. 321322.

Mishra, S. \& Panighrahy, R.C. 1996. Copepods of Bahuda estuary (Orissa), east coast of India. Indian Journal of Marine Science, 25 : 98-102.

Okauchi, M., Zhou, W., \& Zou, W. 1990. Difference in nutritive value of micro algae Nannochloropsis oculata at various growth phases. Nippon Suisan Gakkaishi, 56: $1293-$ 1298.

Payne, M.F., Rippingale, R.J., \&J.J. Cleary, J.J. 2001. Cultured copepods as food for West Australian dhufish (Glaucosoma hebraicum) and pink snapper (Pagrus auratus) larvae. Aquaculture, 194: 137-150.

Rabalais, N.N., Rabalais, S.C., \& Arnold, C.R. 1980. Description of eggs and larvae of laboratory-reared red snapper (Lutjanus campechanus). Copeia, 4: 704-708.

Rhodes, A. \& Boyd, L. 2005. Formulated feeds for harpacticoid copepods: Implications for population growth and fatty acid composition. In C.S. Lee, P.J. O'Bryen, N.H. Marcus (Eds.). Copepods in Aquaculture. Blackwell Publishing, lowa. U.S.A. p. 61-73.

Sargent, J., McEvoy, L.A., \& Bell, J.G. 1997. Requirements, presentation and sources of polyunsaturated fatty acids in marine fish larval feeds. Aquaculture, 155: 117-127.

Schipp, G.R., Bosmans, J.M.P., \& Marshall, A.J. 1999. A method for hatchery culture of tropical calanoid copepods, Acartia spp. Aquaculture, 174: 81-88.

Shansudin, L., Yusof, M., Azis, A., \& Shukri, Y. 1997. The potential of certain indigenous copepod species as live food for commer- 
cial fish larval rearing. Aquaculture, 151: 351356.

Sokal, R.R. \& Rohlf, F.J. 1981. Biometry. W.H. Freeman, New York, U.S.A.

Stottrup, J.G., Richardson, K., Kirkegaard, E., \& N.J. Phil, N.J. 1986. The cultivation of Acartia tonsa Dana for use as live food source for marine fish larvae. Aquaculture, 52: 87-96.

Stottrup, J.G. \& Norsker, N.H. 1997. Production and use of copepods in marine fish larviculture. Aquaculture, 155: 231-247.

Statistical Analysis System. 1996. SASâ Version 6.12 for Windows â. SAS Institute, Inc., Cary, North Carolina, U.S.A.

Steenfeldt, S., Pedersen, P.B., Jokumsen, A., \& Lund, I. 2002. Hatchery production of tropical marine fish in recirculation system. Training Course, Danish Institute for Fisheries Research (DIFRES), The North Sea Centre, Hirtshals, Denmark. 103 pp.

Stottrup, J.G., R. Shields, R., Gillespie, M., Gara, M.B., Sargent, J.R., Bell, J.G., Henderson, R.J., Tocher, D.R., Sutherland, R., Naess, T., Jensen, A.M., Naas, K., van der Meeren, T., Harboe, T., Sanchez, F.J., Sorgeloos, P., Dhert, P., \& Fitzgerald, R. 1998. The production and use of copepods in larval rearing of halibut, turbot and cod. Bulletin Aquaculture Association Canada, 4: 41-45.

Su, H.M., Su, M.S., \& Liao, I.C. 1997. Preliminary results of providing various combinations of live foods to grouper (Epinephelus coioides) larvae. Hydrobiologia, 358: 301 304

Sumiarsa, G.S. 2003. Production and fatty acid profiles of cyclopoid copepod nauplii Apocyclops panamensis. Ph.D Dissertation. Auburn University, Alabama, U.S.A. 170 pp.

Sun, B. \& Fleeger, J.W. 1995. Sustained mass culture of Amphiascoides atopus a marine harpacticoid copepod in a recirculating system. Aquaculture, 136: 313-321.
Treece, G.D. 2000. Zooplankton culture. In Stickney, R.R (ed.). Encyclopedia of aquaculture. John Wiley and Sons, Inc. New York, U.S.A. pp. 1017-1044.

Turk, P. E., Krejci, M.E., \& Yang, W.T. 1998. Laboratory method for the culture of Acartia tonsa (Crustacea:Copepoda) using rice bran. Journal of Aquaculture and Aquatic Sciences, 3: 1-5.

van der Meeren, T. \& Naess, T. 1993. How does cod (Gadus morhua) cope with variability in feeding conditions during early larval stages? Marine Biology, 166: 637647.

Vilela, M.H. 1992. Mass culture and nutritional quality of the marine copepod Tigriopus brevicornis Muller. Boletim Instituto Nacional Investigacao das Pescas, Lisboa, 17: 49-63.

Waspada, Setiawan, Y., \& Rodif, M. 1991. Pengaruh berbagai peningkatan gizi rotifera Brachionus plicatilis terhadap pertumbuhan dan kelangsungan hidup larva ikan kerapu macan Epinephelus fuscoguttatus. J. Penel. Budidaya Pantai, 7: 57-66.

Watanabe, Y., Zenitani, H., Kimura, R., Sato, C., Okumura, Y., Sugisaki, H., \& Oozeki, Y. 1998. Naupliar copepod concentrations in the spawning grounds of Japanese sardine, Sardinops melanostictus, along the Kuroshio Current. Fisheries Oceanography, 7: 101-109.

Witt, U., Quantz, G., Kuhlmann, D., \& Kattner, G. 1984. Survival and growth of turbot larvae Scophthalmus maximus L. reared on different food organisms with special regard to long-chain polyunsaturated fatty acids. Aquacultural Engineering, 3: 177 190. 